\title{
IMPLEMENTASI KEBIJAKAN INOVASI PELAYANAN PUBLIK DI PUSKESMAS JAYA MUKTI DALAM MENINGKATKAN KEPUASAN MASYARAKAT
}

\author{
Trio Saputra, Pebriana Marlinda, Wasiah Sufi \\ Universitas Lancang Kuning \\ e-mail: trio_saputra@unilak.ac.id
}

\begin{abstract}
Public service innovation policies are still new in the implementation of public services at this time. Puskesmas Jaya Mukti is one of the government institutions that innovates through the Optima cycle. The research method used is a qualitative approach, analysis of interactive models and interactive analysis in various qualitative analyzes as a continuous, repetitive and continuous effort. The results of the study showed that the policy implementation of the Proven Health Center using the Optima Cycle had gone well, automatically not making the patient's satisfaction in the Puskesmas increased. The inhibiting factors of the application of cyclical optima are the length of the report download from sikda optima, and in the application of the cyclical optima application there is still no recapitulation of the patient's history below 2016. And the latter requires a supportive policy such as the policy generator used to turn off the lights.
\end{abstract}

Keywords: Implementation, public service, Sikda Optima

Kebijakan inovasi pelayanan publik pada dasarnya masih bersifat baru dalam penyelenggaraan pelayanan publik. puskesmas jaya mukti adalah salah satu intansi pemerintah yang melakukan inovasi melalui sikda optima. Metode penelitian yang digunakan adalah dengan pendekatan kualitatif, analisis digunakan model interaktif merupakan siklus interaktif dalam pengertian analisis kualitatif merupakan upaya yang berlanjut, berulang dan terus menerus. Hasil penelitian menunjukan bahwa implementasi kebijakan inovasi pelayanan dipuskesmas jaya mukti dengan menggunakan sikda optima sudah berjalan dengan baik, sehingga secara tidak langsung membuat kepuasaan pasien puskesmas meningkat. Faktor penghambat dari implementasi sikda optima adalah lamanya download laporan dari sikda optima, serta dalam menjalankan aplikasi sikda optima masih belum dapat merekap riwayat pasien dibawah tahun 2016. Dan yang terakhir butuh penambahan prasarana yang mendukung seperti genset apabila terjadi mati lampu.

Kata Kunci : implementasi, pelayanan publik, Sikda Optima

\section{PENDAHULUAN}

Lahirnya konsep desentralisasi menjadikan pemerintah daerah lebih leluasa dalam menyelenggarakan pemerintahan. Salah satu penyelenggaraan oleh pemerintah daerah adalah pelayanan publik. Pemerintah secara penuh bertanggung jawab terhadap penyelenggaraan pelayanan publik dalam bentuk pelayanan administratif, pelayanan barang dan pelayanan jasa. Oleh sebab itu pemerintah harus berupaya dalam pemenuhan kebutuhan masyarakat. 
Peraturan tersebut didasari dengan terbentuknya Undang-Undang No.25 Tahun 2009 Tentang Pelayanan Publik. Inti dari muatan undang-undang tersebut juga mengatur hak dan kewajiban penyelenggra pelayanan publik agar terciptanya kepastian hukum bagi masyarakat dan penyelenggara, serta terwujudnya pelayanan publik yang layak. Tapi pada kenyataan pelayanan publik indonesia masih tertinggal dari negara ASEAN lainya hasil dari word bank 2018 dapat dilihat dari gambar berikut.

\begin{tabular}{|c|c|c|}
\hline & Negara & $\begin{array}{c}\text { Peringkat } \\
2018\end{array}$ \\
\hline$=$ & Singapura & 2 \\
\hline$=$ & co Malaysia & 24 \\
\hline$=$ & Thailand & 26 \\
\hline$=$ & - Brunei Darussalam & 56 \\
\hline$=$ & * Vietnam & 68 \\
\hline$\overline{\mathrm{e}}$ & Indonesia & 72 \\
\hline$=$ & $\nabla$ Filipina & 113 \\
\hline$=$ & - Kamboja & 135 \\
\hline$=$ & - Laos & 141 \\
\hline$=$ & - Myanmar & 171 \\
\hline$=$ & D Timor Leste & 178 \\
\hline
\end{tabular}

Sumber : World Bank, 2018

Indonesia masih berada deperingkat ke 6, masih tertinggal jauh dari negara ASEAN seperti singapura. Gambaran permasalahan pelayanan publik di indonesia saat ini masih banyaknya pengaduan dan keluhan masyarakat terhadap penyelenggara pelayanan publik yaitu : 1) pelayanan berbelit-belit, 2) tidak transparan, 3) kurang informatif, 4) kurang konsisten, 5) tidak ada kepastian hukum dan 6) terjadinya praktek korupsi, kolusi dan nepotisme. hasil penilaian Ombudsmen Republik Indonesia Tahun 2016 Kondisi yang tak jauh berbeda adalah kondisi pelayanan pemerintah kota yaitu 89,30\% atau 2537 produk layanan di 55 Pemkot belum mampu menyediakan pelayanan khusus bagi pengguna layanan berkebutuhan khusus sebnyak 55.02\% belum melakukan pengukuran kepuasan pelanggaran berarti belum melakukan evaluasi pelayanan publik yang diberikan kepada warga masyarakat.

Penilaian kinerja salah satu bentuk pemantauan dan evaluasi terhadap penyelenggaran pelayanan publik Permenpan RB No. 17 Tahun 2017 Tentang Pedoman Penilaian Kinerja Unit Penyelenggaraan Pelayanan Publik. Penilaian tersebut merupakan hasil dari penyelenggaraan oleh pemerintah daerah untuk dapat memperbaiki penyelengaraan pelayanan publik secara berkelanjutan. Evaluasi Penilaian kinerja pelayanan publik ada beberapa aspek salah satunya adalah inovasi pelayanan publik yang dilakukan intansi pemerintah. Inovasi merupakan wujud perbaikan yang dilakukan untuk mencari solusi yang terbaik dalam penyelenggaran pelayanan publik. Untuk itu hasil yang dinilai dari kinerja pelayanan publik dari kementerian pendayagunaan aparatur negara dan reformasi birokrasi akan meningkat.

Implementasi Peraturan menteri PANRB No. 30 Tahun 2014 tentang pedoman inovasi pelayanan publik. kewajiban yang harus dipenuhi penyelenggara pelayanan publik seperti standart pelayanan dan maklumat pelayanan. Oleh sebab itu peningkatan pelayanan publik dapat dijadikan tolak ukur yang tepat dalam perbaikan pelayanan oleh penyelenggara pemerintah daerah. Perbaikan yang dilakukan pemerintah daerah salah satunya adalah puskesamas jaya mukti kota dumai.

Puskesmas yang berada di kota dumai adalah Puskesmas Jaya Mukti terletak di pemukiman padat akan sangat sulit jika puskesmas masih menjalani pelayanan dengan rekam medik manual oleh karena itu puskesmas merasa perlu melakukan inovasi pelayanan dengan mengembangkan aplikasi sikda generik ke SIKDA OPTIMA online berbasis android. Aplikasi SIKDA OPTIMA merupakan pengembangan dari Aplikasi SIKDA Generik. Dirancang untuk memudahkan melakukan input data, analisis data, penemuan kasus, pengiriman laporan ke berbagai pemegang program di lingkungan Dinas Kesehatan Kota.

SIKDA OPTIMA merupakan sebuah upaya lompatan untuk mendukung pelayanan kesehatan di fasilitas pelayanan kesehatan dasar, meningkatkan ketersediaan dan kualitas data serta informasi kesehatan melalui pemanfaatan teknologi informasi. Dari penerapan SIKDA OPTIMA oleh puskesmas 
jaya mukti, peneliti tertarik untuk dapat mendiskripsikan "Implementasi Kebijakan Inovasi Pelayanan Publik Di Puskesmas Jaya Mukti Dalam Meningkatkan Kepuasan Masyarakat”.

\section{METODE}

Penelitian ini menggunakan metode deskriptif pendekatan kualitatif. Penelitian ini mendiskripsikan data yang diperoleh dari hasil penelitian mengenai implementasi kebijakan inovasi pelayanan publik di puskesmas jaya mukti dalam meningkatkan kepuasan masyarakat. Data dihimpun dengan pengamatan yang seksama, mencangkup deskripsi dalam konteks yang mendetil disertai catatancatatan hasil wawancara yang mendalam, serta hasil analisis dokumen dan catatan.

Analisis data adalah proses menyusun dan menggabungkan data ke dalam pola, tema, kategori, sedangkan penafsiran adalah memberikan makna kepada analisis, menjelaskan pola atau kategori, dan mencari hubungan antara beberapa konsep. Penafsiran menggambarkan perspektif peneliti bukan kebenaran. Analisis dan penafsiran data dalam penelitian kualitatif pada dasarnya bukan merupakan hal yang berjalan bersama, keduanya dilakukan sejak awal penelitian. Analisis data dilakukan agar data yang telah diperoleh akan lebih bermakna. Analisis data merupakan proses penyederhanaan data kedalam bentuk yang lebih mudah dibaca dan diinterprestasikan.

Miles dan Huberman (1992: 20) menjelaskan analisis data adalah proses mencari secara sistematis dan mengatur catatan wawancara, catatan lapangan, dan rider lain yang dihimpun untuk menggiring pengertian. Analisis tersebut melibatkan kerja dengan data, mengaturnya, memisahkan kedalam unit-unit yang dapat dikelola, memadukannya, mencari-cari pola memenuhi hal-hal penting dan apa yang diketahui dan memutuskan apa yang akan disampaikan kepada orang lain. Analisis data penelitian ini, bila dinyatakan dalam bentuk gambar adalah sebagai berikut:

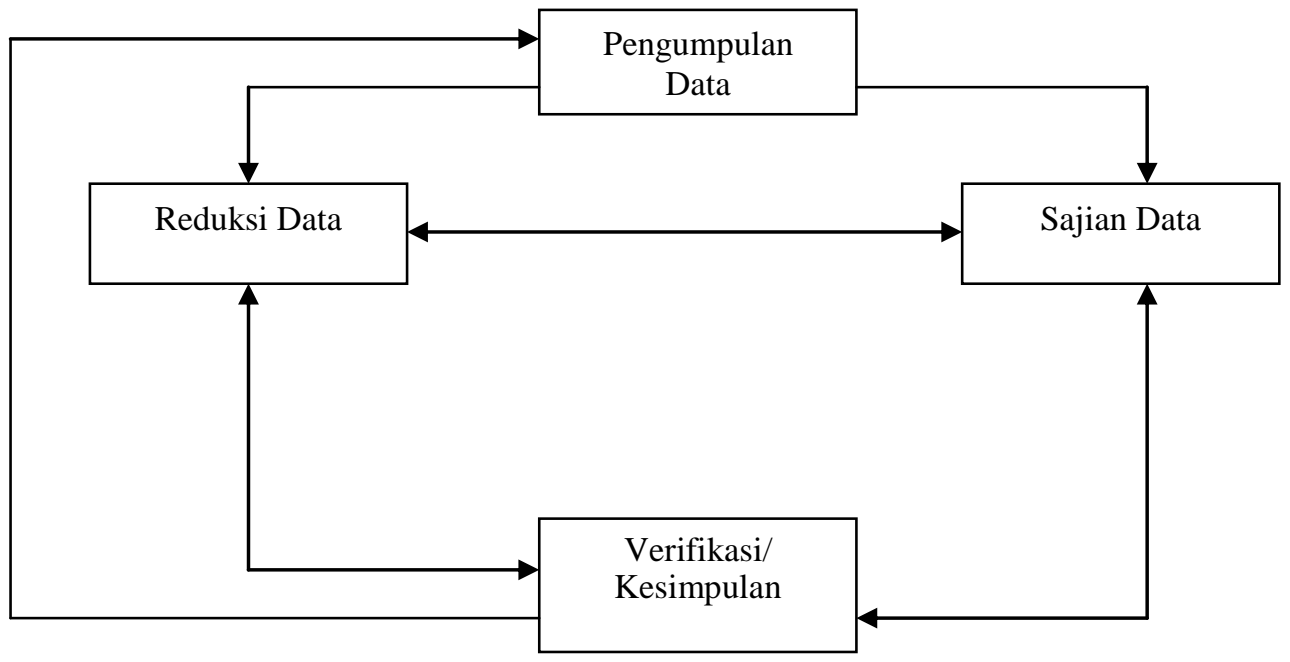

Gambar 3 (Miles dan Huberman, 1992: 20)

Tahap-tahap tersebut merupakan kegiatan yang harus diperhatikan dalam analisis data kualitatif. Kegiatan pengumpulan data, reduksi data, penyajian dan penarikan kesimpulan/verifikasi dalam analisis model interaktif merupakan siklus interaktif dalam pengertian analisis kualitatif merupakan upaya yang berlanjut, berulang dan terus menerus 


\section{HASIL DAN PEMBAHASAN}

\subsection{Implementasi kebijakan inovasi pelayanan publik di puskesmas jaya mukti dalam meningkatkan kepuasan masyarakat}

Kebijakan publik menurut Thomas Dye adalah apapun pilihan pemerintah untuk melakukan atau tidak melakukan (public policy is whatever governments choose to do or not to do). Konsep tersebut sangat luas karena kebijakan publik mencakup sesuatu yang tidak dilakukan oleh pemerintah di samping yang dilakukan oleh pemerintah ketika pemerintah menghadapi suatu masalah publik. Selanjutnya Kaplan (2014: 18) mengatakan bahwa kebijakan publik sebagai a projected program of goals, values and practices (Suatu program pencapaian tujuan, nilai-nilai dan praktek-praktek yang terarah) dan juga mengemukakan bahwa kebijaksanaan publik sebagai suatu taktik dan strategi yang diarahkan untuk mencapai suatu tujuan.

Makna kebijakan publik merupakan serangkaian tindakan pemerintah guna melaksanakan suatu kegiatan yang diawali dari pembuatan atau perumusan, pelaksanaan dan penilaian atau evaluasi kebijakan. Mengacu pada pandangan dari beberapa pakar kebijakan publik, maka dapat dikatakan bahwa kebijakan inovasi pelayanan publik melalui Sikda Optima dilaksanakan oleh puskesmas jaya mukti kota dumai merupakan langkah kebijakan publik dengan dasar hukum Permen PANRB No. 30 Tahun 2014 Tentang Pedoman Inovasi Pelayanan Publik.

Awal puskesmas jaya mukti kota dumai melakukan inovasi pelayanan menggunakan SIKDA OPTIMA pada Tanggal 12 Bulan Maret Tahun 2016, melalui surat keputusan kepala puskesmas No: 10/SK/JM/2016 tentang pengelola elektronik medical record (e-medrec) SIKDA OPTIMA terintegrasi Pcare BPJS kesehatan Oneline, program SIKDA OPTIMA merupakan inisiasi yang dilakukan oleh kepala puskesmas, dokter, bidan, perawat, petugas gizi dan rekam medik. Setelah dilakukan rapat diusulkanlah sebuah aplikasi SIKDA OPTIMA yang merupakan pengembangan dari sikda generik dari kementerian kesehatan

Pelaksanaan kebijakan inovasi SIKDA OPTIMA dilakukan pihak puskesmas dengan sosialisasi lintas sektoral serta bidan desa dan kader juga wajib melakukan sosialisasi kepada masyarakat. Sosialisasi tersebut awalnya dilakukan setiap minggu dan terus berlanjut sampai satu tahun, dan pada tahun berikutnya hanya dilakukan satu bulan sekali. Program SIKDA OPTIMA ini masih berjalan sampai pada tahun ini dengan peningkatan fitur didalam programnya. Pengembangan fitur tersebut tidak lain dalam mengatasi permasalahan yang ada dilapangan seperti saat ini telah ditambah poli jiwa diaplikasi SIKDA OPTIMA.

Pemahaman terhadap prosedur pelaksanaan kebijakan oleh pegawai puskesmas jaya mukti sudah dipahami dengan baik Secara keseluruhan Pegawai Puskesmas Jaya Mukti mengetahui prosedur tentang kebijakan SIKDA OPTIMA dimana pengelolaan Sistem Informasi kesehatan daerah adalah salah satu fungsi dari Puskesmas, untuk menujang Implementasi SIKDA OPTIMA di Puskesmas Jaya Mukti adalah dengan mengoperasionalkan sistem Oneline diharapkan lebih memberikan kemudahan dalam memberikan pelayanan kesehatan.

Jumlah pegawai puskesmas jaya mukti adalah sebanyak 65 orang, pelaksanaan program SIKDA OPTIMA tersebut dibantu oleh tenaga IT dari dinas kesehatan. Penggunaan aplikasi SIKDA OPTIMA tersebut dilakukan oleh tenaga IT kepada pegawai puskesmas jaya mukti. Selanjutnya tenaga IT tersebut membantu di puskesmas jaya mukti apabila terjadi kendala dalam penggunaannya.

Prasarana dalam mendukung program ini adalah server, tab, mesin standing nomor antrian, kartu berobat dan tv informasi. Pembiayanaan awal dilakukan puskesmas jaya mukti dari BLUD sebesar 60 juta. Pengembangan program ini terus dilakukan untuk memberikan pelayanan yang terbaik oleh pihak puskesmas. Dengan adanya Kombinasi antara sumber daya manusia dan prasarana dalam menjalankan inovasi pelayanan SIKDA OPTIMA ini dirasa sangat baik, sumber daya yang mendukung pelaksanaan 
akan mempermudah menjalankan program SIKDA OPTIMA sesuai dengan apa yang diharapkan serta prasarana penunjang program SIKDA OPTIMA menjadi faktor keberhasilan dalam pelaksanaanya.

Sikap pegawai sendiri merupakan faktor yang amat penting untuk suksesnya implementasi. Jika pelaksana berpandangan positif terhadap suatu kebijakan, maka kemungkinan besar mereka akan melaksanakan apa yang dikendaki oleh pembuat kebijakan. Tetapi bila sikap atau perspektifnya berbeda, maka proses implementasi menjadi terancam kesuksesannya.

Untuk menjalankan sesuai dengan tujuan program SIKDA OPTIMA yang pertama adalah dengan Pendekatan perilaku dengan membuat komitmen bersama pegawai puskesmas dalam menjalankan SIKDA OPTIMA, kedua adalah penggunaan data informasi untuk penyelenggaraan upaya kesehatan yang efektif dan efisien serta mendukung tata kelola kepemerintahan yang baik untuk mewujudkan pelayanan prima kepada masyarakat

Lahirnya kebijakan inovasi pelayanan menggunakan SIKDA OPTIMA dari permasalahan yang terjadi seperti waktu tunggu pasien yang lama, kedua tidak terdatanya riwayat penyakit pasien yang berobat secara realtime dan ketiga database pasien puskesmas tidak terupdate. Oleh sebab itu perlunya pembenahan dalam menjalankan system yang ada, berawal dari Pengusulan pemecahan masalah pelayanan di puskesmas dibahas didalam rapat forum internal puskesmas untuk mencari ide inovatif dalam pelayanan, pihak puskesmas yang didalamnya terdapat kepala puskesmas, dokter, bidan, perawat, petugas gizi dan rekam medik. Setelah dilakukan rapat diusulkanlah sebuah aplikasi SIKDA OPTIMA yang merupakan pengembangan dari sikda generik dari kementrian kesehatan.

Dengan aplikasi SIKDA OPTIMA yang disesuaikan dengan kebutuhan puskesmas. Dirancang untuk memudahkan melakukan input data, analisis data, penemuan kasus, pengiriman laporan ke berbagai pemegang program di lingkungan dinas kesehatan kota. Dengan SIKDA OPTIMA diharapkan aliran data dari tingkat bidan di kelurahan, puskesmas sampai ke tingkat dinas kesehatan kota dumai mudah di akses secara online. Sehingga perkembangan data kesehatan bisa realtime, laporan tepat waktu, efektif, efisien dan bermanfaat untuk penyusunan perencanaan pembangunan kesehatan. Dengan teknologi dari perangkat selalu berkembang dan sehingga sistem mengikuti perkembangan dengan terus menerus. Aplikasi Android dengan E-MedRec dengan efektivitas mobile membuat user makin mudah dan interface User friendly.

Teknis yang digunakan meliputi aplikasi server data, SOP dan aturan terkait. Teknik yang dipakai di puskesmas diantara sistem data yang lebih mengandalkan teknologi informasi yang langsung terhubung dalam sistem informasi BPJS dan dinas kesehatan. Perangkat komunikasi menggunakan handphone yang berbasis android. Dengan mendownload home visit di google store dengan nama aplikasi "salam sehat dumai madani". Teknik pengumpulan data pasien, selain dari BPJS puskesmas juga mendata pasien setiap kegiatan lapangan diwilayah kerja puskesmas Jaya Mukti. Selain itu kelengkapan administrasi layanan juga dipenuhi seperti surat keputusan dinas kesehatan kota Dumai. Demikian dengan SOP dalam pelaksanaan untuk menjamin kualitas pelayanan. Dan disetiap poli petugas juga menginstruksikan pasien menilai layanan di tablet kepuasan pasien terhadap pelayanan yang diberikan puskesmas jaya mukti sehingga kepala puskesmas dapat memonitoring dan mengevaluasi kinerja pegawai secara langsung.

\subsection{Kepuasan masyarakat}

Kebijakan inovasi pelayanan publik melalui SIKDA OPTIMA diharapkan dapat memberikan kepuasan kepada masyarakat/pasien baik mengenai kuantitas dan kualitas. sarana dan prasarana yang tersedia maupun peningkatan pelayanan serta budaya kerja pegwai puskesmas jaya mukti. Dengan adanya inovasi pelayanan menggunakan SIKDA OPTIMA akan dapat menimbulkan kepercayaan masyarakat kepada penyelenggara pelayanan publik khususnya puskesmas jaya mukti. Bagi masyarakat sebagai pasien diuntungkan dengan pelayanan yang cepat dan mudah. 
Sistem informasi database pasien berbasis oneline yang terhubung langsung dengan aplikasi SIKDA OPTIMA dan bpjs. Dengan adanya data base pasien akan membantu rekam medis pasien yang berobat seperti riwayat penyakit, alergi dan stok obat dipuskesmas serta dapat mengetahui penyakit terbanyak selama sebulan terakhir.

Serta dengan adanya tablet kepuasan pasien pengguna layanan puskesmas, kepala puskesmas dapat memonitoring dan evaluasi kinerja bawahannya secara langsung. Dan didukung Kartu e-berobat, untuk identitas pasien mendapatkan akses pelayanan, dengan adanya kartu e-berobat mengantisipasi hilangnya kartu bpjs dan ktp. Sehingga pasien dapat menggunakan kartu ini ketika menggunakan pelayanan di puskesmas jaya mukti.

Pasien mendapatkan pelayanan efektif dan efesien dengan prosedur layanan yang mudah dan singkat dalam waktu pelayanan. Ketika pasien berobat kepuskesmas dengan pelayanan menggunakan aplikasi SIKDA OPTIMA bisa mempercepat waktu pelayanan.Sebelumnya untuk berobat kepuskesmas harus mengantri lama karena pegawai harus mencari data pasien yang disimpan secara manual baru merujuk ke poli yang dituju, dan waktu pelayanan ini membuat pasien menunmpuk di loket pelayanan.

Sesudah menggunakan aplikasi SIKDA OPTIMA pasien masuk dalam data base bpjs dan puskesmas dengan kartu bpjs, ktp dan kartu eberobat. Pasien tinggal mengambil nomor antrian diloket layanan dan menscan kartu setelah itu tinggal memilih mana poli yang akan dituju, proses pelayanan menggunakan SIKDA OPTIMA ini hanya memakan waktu selama lima menit.

Terupdatenya database pasien secara realtime ke bpjs, dinas kesehatan dan puskesmas dan seluruh unit kerja puskesmas termasuk bidan desa. Sebelumnya database bpjs tidak update secara langsung ke puskesmas karena tidak menggunakan sistem oneline. Contoh. Budi adalah pasien puskesmas ingin merujuk pelayanan ke rumah sakit, data dari bpjs tidak terlihat pembayan iuran secara langsung dan riwayat medis pasien juga tidak ada didalam database bpjs. Sesudah adanya aplikasi SIKDA OPTIMA. Setiap pasien berobat terupdate langsung ke bpjs dan dinas kesehatan dan terekamnya riwayat penyakit pasien secara langsung. Dan proses rujukan juga menjadi mudah karena langsung dirujuk dari dokter ke poli kerumah sakit yang terhubung langsung ke bpjs

\subsection{Faktor- faktor penghambat kebijakan inovasi pelayanan SIKDA OPTIMA}

Faktor penghambat yang dihadapi puskesmas dalam menjalankan aplikasi SIKDA OPTIMA adalah lamanya proses download laporan dari SIKDA OPTIMA, karena file didalam SIKDA OPTIMA cukup besar untuk di download, untuk penyelesaian hal tersebut pegawai puskesmas akan mendownload laporan kinerja tersebut tiga hari sebelum waktu yang ditentukan.

selanjutnya masih belum terlihat riwayat penyakit keluarga sebelumnya kerena puskesmas jaya mukti baru mengoperasikan aplikasi ini sebelum 2016 jadi untuk riwayat penyakit keluarga pasien sebelum 2016 tidak bisa terdeteksi. Penyelesaiannya adalah melengkapi data pasien yang di input 2016. serta perlengkapan sarana dan prasarana pendukung, seperti penambahan kouta internet untuk mengoperasikan aplikasi ini, dan kendala ketika mati lampu penyelesaianya adalah dinas kesehatan kota dumai telah memberi bantuan kouta internet kepada puskesmas jaya mukti sebesar $10 \mathrm{~GB}$, selanjutnya pihak puskesmas mempersiapkan Genset apabila terjadi mati lampu, karena kebutuhan listrik sangat diperlukan untuk mengoprasionalkan proses pelayanan

\section{KESIMPULAN}

Implementasi kebijakan inovasi pelayanan SIKDA OPTIMA oleh puskesmas jaya mukti masih perlunya dukungan stakeholder antara pemerintah, swasta dan masyarakat Karena penyelenggaraan pelayanan publik berkaitan dengan kesehatan merupakan kewajiban dan termasuk dalam pelayanan dasar. 
Pemerintah daerah harus dapat meningkatkan dan terus mencari inovasi pelayanan kesehatan, untuk terus meningkatkan pelayanan dan mewujudkan pelayanan prima kepada masyarakat. Dengan adanya aplikasi SIKDA OPTIMA tidak lepas dari dukungan dinas kesehatan dumai yang mensuport puskesmas dalam pelaksanaan inovasi pelayanan dibidang kesehatan. Inovasi pelayanan sikda optima masih perlu ditingkatkan dari sarana dan prasarna pendukung untuk dapat menjalakan program ini dengan baik.

\section{UCAPAN TERIMA KASIH}

Terima kasih kami ucapkan sebesar-besarnya kepada Direktorat Jenderal Penguatan Riset dan Pengembangan melalui Direktorat Riset dan Pengabdian kepada Masyarakat (DPRM) RISTEK DIKTI yang telah memberikan bantuan dana penelitian sebesar Rp 22.500.000,- (Dua Puluh Dua Juta Lima Ratus Ribu Rupiah) tahun anggaran 2018. Sesuai dengan kontrak penelitian nomor : 007/kontrakpenelitian/K10/KM/2018.

\section{DAFTAR PUSTAKA}

[1].Anderson, James E, 2013. Public Policy Making-An Introduction. (second edition). Texas A : M University.

[2].Arikunto, S. 2010. Manajeman Penelitia., Jakarta: Rineka Cipta.

[3].Dailiati, S., \& Saputra, T. (2018, May). Rising Pendapatan Asli Daerah (PAD) in Pekanbaru: Billboard Planning Policy Tax. In IOP Conference Series: Earth and Environmental Science (Vol. 156, No. 1, p. 012032). IOP Publishing.

[4].Edwards III, G.C., dan Sharkansky, I. 2012. The Policy Predicament. San Fransisco: W.H. Freeman and Company.

[5].Halilintar, M. P. (2017). Evaluasi Kebijakan Tentang Kerjasama di Universitas X. Jurnal Niara, 10(1), 20-27.

[6].Indriantoro, Nur dan Bambang Supomo. 2012. Metodologi Penelitian Bisnis Untuk Akuntansi dan Manajemen. Edisi Pertama. Yogyakarta: BPFE Yogyakarta.

[7].Kaplan, Abraham, 2014, Power and Society, Yale University Press, New Haven

[8].Miles, Matthew B dan Huberman, A. Michael. 1992. Qualitative Data Analysis. New York: Sage Publications, Inc.

[9].Nugroho, Riant D., 2010. Otonomi ; Desentralisasi Tanpa Revolusi, Kajian dan Kritik atas Kebijakan Desentralisasi di Indonesia. Jakarta: PT.Elex Media Komputindo.

[10].Permen PAN RB No.17 Tahun 2017 Tentang Pedoman Penilaian Kinerja Unit Penyelenggara Pelayanan Publik

[11].Permen PAN RB No.30 Tahun 2014 Tentang Pedoman Inovasi Pelayanan Publik 
[12].Saputra, T. (2018). Capaian Pelayanan Kesehatan Dasar Di Kota Pekanbaru. Jurnal Ilmu Sosial, $16(1), 47-57$.

[13].Saputra, T \& Marlinda, P (2018) Services Innovation of Sikda Optima Program at Puskesmas Jaya Mukti Dumai City. International Journal of Science and Research (IJSR) Vol 7 No. 6, Hlm 723-728

[14].Saputra, T., \& Sufi, W. (2018). Strategi Dalam Memberikan Pelayanan Kepada Masyarakat. Jurnal Benefita: Ekonomi Pembangunan, Manajemen Bisnis Dan Akuntansi, 3(3), 396-416.

[15].Sunggono. 2012. Hukum dan Kebijakan Publik. Jakarta: Sinar Grafika.

[16].Undang-Undang Nomor 23 Tahun 2014 tentang Pemerintahan Daerah

[17].Undang-Undang Nomor 25 Tahun 2015 tentang Pelayanan Publik

[18].Wahab, Solichin Abdul. 2011. Analisis Kebijakan-Dari Formulasi ke Implementasi Kebijaksanaan Negara. Jakarta : Bumi Aksara. 